\title{
2015 年日本地理学会秋季学術大会および秋季代議員会記録
}

\author{
(於 愛媛大学)
}

\section{5 年秋季代議員会記事}

2015 年度第 1 回代議員会は, 2015 年 9 月 18 日

(金) 10 時 30 分 11 時 40 分, 愛媛大学共通教育棟 11 番教室にて開催された。

呉羽総務専門委員長の開会の辞, 荒井会長の挨 拶，寺谷大会実行委員長の会場校挨拶があった，次 に中村周作代議員を議長に選出し，田林総務専門委 員に書記を委嘱した。呉羽総務専門委員長より, 総 会としての成立が確認された（出席者 33 名, 委任状 提出者 59 名, 合計 92 名).

\section{I. 報告事項}

\section{1. 通常会務報告}

菊地理事長より, 学会の倫理規程の決定, 地理学 評論の電子投稿システムの定着化, 広報専門委員会 による高校生ポスターセッションの状況, 第 10 回 中日韓地理学会議への協力体制などが報告された.

2. 財務状況について

江崎財務委員長より, 資料 1 に基ついて平成 27 年 4 月 1 日〜 8 月 31 日までの財務状況が報告された.

3. 2015 年度 GIS 学術士等 ·地域調査士等の認定 について

菊地理事長より, 資料 2 に基づいて, GIS 学術士扔 よび地域調查士等の認定状況が報告された。また, 今年度の資格認定者と今後の講習会の予定が紹介さ れた，課題や検討事項として，地域調查士のさかの ぼり認定, 地域調査士・GIS 学術士の社会的重要性 を高める工夫, 地域調査士 · GIS 学術士についての 商標登録の 3 点が報告された.

4. 2015 年度出版助成について

菊地理事長より, 資料 3 に基づいて, 2015 年度出 版助成対象として 2 点の著作が採択されたことが報 告された。

\section{II. その他}

1. 国際地理オリンピック実行委員からの報告お よび地理の高等学校での必修化について

井田地理教育専門委員長より，モスクワ大会では 参加国が 40 カ国, 日本は銀メダル 3, 銅メダル 1 を獲得し, 参加者すべてが受賞したことが報告され
た. 高等学校の地理の必修化に向けたタスクフォー スの活動について報告があり, 今後は魅力的なカリ キュラムの提示に向けた準備が必要との認識が示さ れた。

\section{IGU 報告}

水見山代議員より，資料 4-1，4-2，4-3に基づい てモスクワでIGUの国際会議が開催され, 日本人 の参加者が全体の 4 番目と多かったことが報告され た. 2018 年はカナダのケベックで開催予定, 2020 年のIGCはイスタンブールで開催予定であることが 報告された.

\section{3. 日本学術会議活動報告}

水見山代議員より, 日本学術会議の活動について報 告があった. 特に, 地球人間圈会議では居住地決定に 関するシンポジウムに多くの人が参加され盛況であっ たと報告された。 また, 資料 5 に基づいて日本学術会 議の公開ワークショップについて説明があった.

4. その他

高木代議員より, 地理学評論をサイテーションイ ンデックスに入れるべきとの要望があり, 今後, 理 事会で検討していくことになった.

松本代議員より, 地球惑星科学連合で発行する雑 誌についてサイテーションインデックスやインパク トファクターが付与される予定との報告があり, 投 稿の呼びかけがあった。

戸所代議員㧍よび岡本代議員より, 高校で地理を 教える教員に対して学会としてのバックアップを検 討すべきとの意見があった，これに関して，理事会 で対応を検討していくことになった．

戸所代議員より大学の人文社会系・教育系の改組 に関する学会としての取組みについて意見があっ た，今後は，情報収集を含めて理事会で検討してい くことになった。

以上で議事を終了し, 中村議長による書記の解任 と議長の解任が行われた後, 吳羽総務専門委員長の 閉会の辞をもって, 2015 年度第 1 回代議員会は終了 した. 


\section{出版 助 成 委員 会 答申}

\section{出版助成委員会}

委員長 横山 智

日本地理学会では，2015 年 6 月 1 日〜30 日に出 版助成対象となる地理学に関する学術図書の募集を 実施した。その結果，3点の応募があった。

出版助成委員会の各委員が対象図書に対して0〜 10 点の範囲で評価点をつけるとともに，400 字以内 で簡潔に記した評価内容を委員長宛てに8月 10 日 までに送付した。なお，委員が共著者となっている 図書の応募があったため，共著者となっている場合 は，その申請に関しては評価・コメントをしないこ ととした

委員長は総合点数を評価者数で割った平均点を もって順位付けし，その集計結果および評価コメン 卜を全委員にメールで送付して再度意見を求めた。 その際, 3 点の応募図書は積極的にその研究成果を 社会にアピールすべき内容を含んでおり，優越を付 けがたいが，7点以上の高い得点が得られた上位 2 点を推薦する原案を各委員に伝達した。それに対し て指定期日の 8 月 15 日まで特段の異論がなかった。

この選考結果を踏まえて, 申請された 3 件のうち 上位 2 点をここに推薦する.

\section{交付認定者：藤本 潔会員}

藤本 潔·宮城豊彦·西城 潔 ·竹内裕希子編『微 地形学』(古今書院)

本書は, 2014 年日本地理学会春季学術大会での シンポジウム「微地形と地理学——その応用と展 開—」の発表内容を中心にまとめたものである.
また, 筆者の一人である田村俊和先生の退職記念出 版図書でもある。自然地理学的な研究成果にとどま らず，防災への応用も含め, 微地形をテーマに自然 と人間との関係が多面的に論じられており, 地理学 の研究成果として学術的意義は高い. また, 「微地 形と自然環境」,「微地形と自然災害」,「微地形と人 間活動」に分けられた各部には，専門的な「論説」 だけではなく,「総説」や「トピック」を配し, より 幅広い理解が得られるように工夫されている。これ らの点を評価して, 本書は本助成の趣旨に十分適う ものと判断できる.

\section{交付認定者：山下清海会員}

山下清海編『世界と日本の移民エスニック集団とホ スト社会』(明石書店)

本書は, 編者が代表を務めた科研費基盤研究 (A) のメンバーによる共同研究成果をまとめたものであ る。海外および国内に扔けるエスニック・コンフリ クトやエスニック資源という観点から, ホスト社会 における移民問題について議論した論集であるが, II 章で全体の研究テーマを読み解くためのキーワー ドの解説がなされており, 一冊の単行本としてうま く編まれている。近年, 隣接分野でも移民問題に関 する図書が多く刊行されている中, フィールドワー クに基づく実証的な研究成果を前面に打ち出した内 容となっている本書は, 地理学の有用性をアピール することに大きく貢献しうる。これらの点を評価し て, 本書は本助成の趣旨に照らし合わせると高く評 価できる.

\section{学 術大会記 事}

2015 年秋季学術大会は，9月 18 日（金）～19日 （土）に愛媛大学において開催され, 有料参加者 456 名（正会員 311 名, 学生会費納入正会員 65 名, 非 会員 80 名), 名誉会員・交付認定者等の参加があっ た。

学術研究発表は 9 月 18 日 (金) 19 日 (土) の両 日に 9 会場で一般発表（ポスター発表を含み, 177 件）と, 計 21 件の発表を含む三つのシンポジウム が行われた。シンポジウムは18日に「現代中国の 都市地理学」(研究動向, 都市構造の再編で生じたさ まざまな問題について 8 件の発表があり, 中国にお ける都市研究の現状について意見交換し, 今後のあ
り方について議論された．参加者約 70 名), 19 日に 「地方創生に向けたまちづくりに対する大学の役割」 (東北各県のまちづくりに関わる 6 人の研究発表を もとに, 地方創生に向けた大学の役割について活発 な議論が交わされ, 大学間連携の重要性が指摘され た. 参加者約 40 名),「20 世紀の都市地理学から 21 世紀の都市地理学へ」(7 本の報告, 討論では都市地 理学のそれぞれの分野の総括と展望を述べるととも に, 都市地理学の日本学派の成立の可能性について 活発な意見交換が行われた. 参加者 75 名), が行わ れた。

9月 19 日には, 地理教育公開講座「南アジア \& 
フリカ世界地誌 Q \& A」が開催され, 懇親会は生協 食堂に扔いて, 221 名が参加する盛会であった。

また，各研究グループの集会が行われた，

9 月 20 日（日）には，巡検第 1 班「四国西予ジオ パークを歩く・見る・聞く」(案内者 3 名を含め参加 者 22 名), 第 2 班「愛媛県南予地方の飲食文化」(案 内者 4 名を含め参加者 20 名), が実施され, 有意義
な現地討論がなされた。

寺谷亮司実行委員長はじめ大会役員拈よび愛媛大 学の学生諸君には, 多大な御協力をいただいたこと に深く感謝の意を表するものである，最後に各会場 で座長の労をとられた会員, 巡検案内にあたられた 会員の行き届いた準備にたいして心からお礼を申し 上げる. 